\title{
Legal Protection of Customers in Credit Agreements with Collateral of Land Rights
}

\author{
D Andara $^{1 *}$, IK Dewi ${ }^{1}$, FM Ramadhan ${ }^{2}$, Hardin $^{3}$ \\ ${ }^{1}$ Department of Law, Faculty of Law, Universitas Muhammadiyah Buton, Baubau, Indonesia \\ ${ }^{2}$ Department of Law, Faculty of Law, Universitas Hasanuddin, Makassar, Indonesia \\ ${ }^{3}$ Department of Agribusiness, Faculty of Agriculture, Universitas Muhammadiyah Buton, Baubau, Indonesia \\ *Corresponding author. Email: darojatandra@gmail.com
}

\begin{abstract}
Economic development as part of national development, is one of the efforts to create a just and prosperous people's welfare based on the Pancasila and the 1945 Constitution of the Republic of Indonesia. The purpose of this study was to determine the form of legal protection for customers in credit agreements with land rights collateral at Bank Syariah Mandiri Baubau Branch. This study was conducted at the Bank Syariah Mandiri Baubau Branch. Samples from this study were 13 informants. Sampling of customers will be done by simple random sampling, The form of legal protection for customers (mudharib) is: (a) the Bank Syariah Mandiri Baubau Branch Office will store the mudharib file into the hasanah room and secure it in a safe monitored through closed circuit television (cctv) and alarmed, where the room is anti-fire and flood and theft; (b) There is a security guarantee from the officer, with a 24 hour security system, so that the mudharib file will be protected from the danger of theft; (c) There is legal protection for mudharib in accordance with Article 38 paragraph (1) of the Law of the Republic of Indonesia Number 21 of 2008 concerning Sharia Banking; (d) There are opportunities for mudharib to learn the terms of the financing agreement, so that the mudharib do not feel cheated.
\end{abstract}

Keywords: legal protection, customers, credit agreements, collateral, land rights

\section{INTRODUCTION}

Economic development as part of national development, is one of the efforts to create a just and prosperous people's welfare based on the Pancasila and the 1945 Constitution of the Republic of Indonesia. In the context of increasing national development that focuses on the economic field, the actors include the government and the community as individuals and legal entities, very large amounts of funds are needed through credit.

The bank is a business entity that has a strategic position to encourage national economic growth. In running its business, the bank functions as intermediary institutions by collecting funds from the public and channeling them in form of credit [1].

Law of the Republic of Indonesia Number 10 of 1998 concerning Amendment to Law of the Republic of Indonesia Number 7 of 1992 concerning Banking, which was promulgated on November 10, 1998, marks a new history in the field of banking which began to implement a dual banking system (dual system banking) in Indonesia, namely the system conventional banking with interest devices and banking systems with contractual agreements that are in accordance with sharia principles[2].

Credit in Banking activities is the most business activity the main, because the biggest income from Bank business is derived from income from credit business activities in the form of interest and provision. The scope of credit as an activity Banking, is not merely a form lending activity to customers but it is very complex because concerning the elements of customer relations which quite a lot of them include: sources of creditor funds, allocation of funds, credit organization and management, credit policy, documentation and credit administration, credit supervision as well settlement of problem loans. Remembering so broad in scope and elements which includes this credit activity, then not excessive handling must very carefully done with supported by professionalism and integrity moral must be attached to resources humans and credit officials are [3]. Judging from the form, the credit agreement banking in general uses form of standard agreement. Related to that, it is indeed deep practically the form of the agreement is already provided by the bank as a creditor whereas debtors learn a lot and understand it well. Agreement which is this is commonly called an agreement standard [4].

Community service users at banking institutions are commonly called bank customers. There are 2 (two) types of bank customers, depositors and borrowers. In terms of customers depositors, the reasons for the customers to deposit their funds in a bank are for security purposes, in this case the security of funds deposited in a bank is more secure than keeping it at home. In terms of borrowing customers, reasons a customer borrowing funds from a bank is a relatively smaller loan interest compared to borrowing from moneylenders or loan shark [5].

Banking developments from year to year continues to increase. With the issuance of Law Number 10 of 1998 concerning Amendments to Law Number 7 of 1992 concerning Banking, which was promulgated on November 10, 1998, marked a new history in the field of banking which began to enact a dual banking system in Indonesia, 
namely the system conventional banking with interest devices and banking systems with contractual agreements that are in accordance with sharia principles [6].

In bank practice there are 2 (two) forms of credit agreement, namely underhand deed and notarial deed. In lending and borrowing activities money is often required for the delivery of debt guarantees from the creditor to the debtor. Debt guarantees are also called credit or collateral. Credit guarantees function to secure credit repayment when the debtor defaults or is called default. In the banking practice, credit guarantees used are generally special guarantees, namely material security in the form of land[7].

Collateral given by the debtor to the bank very diverse types and shapes but deep one of the known banking businesses is collateral in the form of land, i.e. land that has rights to certain land that has been regulated by law which can be encumbered with Mortgage Rights. Right The dependents themselves are in accordance with Law Number 41996 concerning mortgage rights understanding that Mortgage is a right collateral charged to land rights as referred to in the Act Number 5 of 1960 concerning Basic Agrarian Basic Regulations, whether or not the following objects are another part of the land, for repayment of certain debts, which give preferred position for certain creditors against other creditors [8].

Creditors as recipients of Underwriting Rights, will get a deed of mortgage. After get a deed of Mortgage, then creditors necessarily have execution rights directly, as happens in lending and borrowing in banking. The legal strength of the deed is the same as a court decision that has permanent legal force [9].

In a loan, bank or the giver always hopes that the debtor can fulfill his obligations to pay off on time to credit he has received. In practice, no all credit issued by the bank can run and end smoothly. Not a few also the occurrence of problem loans caused by the debtor unable to pay off the credit is on time as is agreed in the Credit Agreement between the debtor and the banking company. The things that cause problem loans for example because the debtor does not able or due to decline effort and failure of business that results reduced debtor business income or indeed, the debtor does not want to pay as soon as possible because the debtor's character is not good [10].

Based on the background description that has been explained, then in this legal research the writer wants to know: (1) What is the process of credit agreement with collateral rights to land between the customer and Bank Syariah Mandiri Baubau Branch? (2) What is the form of legal protection for customers and creditors in a loan agreement with a collateral for land rights at Baubau Bank Syariah Mandiri Branch?; (3) What are the steps taken if there is a default between the customer and the Bank Syariah Mandiri Baubau Branch?

\section{METHOD}

This research was conducted at the Bank Syariah Mandiri Baubau Branch and the implementation of the research is planned to be carried out from May to July 2019.

The types and sources of data used as a basis for supporting the results of this study are: a. Primary data, namely data taken directly from the field or from the Bank Syariah Mandiri Baubau Branch through interviews with respondents in this case the leaders and employees of Bank Syariah Mandiri Baubau Branch, as well as the customers.

b. Secondary data, which is sourced from a variety of literature, magazines, brochures and company documents in the form of credit agreements between the Bank Syariah Mandiri Baubau Branch with customers.

Population is the whole subject of research consisting of humans, objects, animals, plants, symptoms, test scores or events as a source of data that has certain characteristics in a study [11].

In this regard, the population of this study consists of all management of the Bank Syariah Mandiri Branch of Baubau including customers who use collateral rights to land during the last 2 (two) years, namely the realization of 2014 and 2015.

Samples are part of a population. The sample consists of a portion of members selected from the population. In other words, some and not all, elements of a population will form a sample [12]

Based on this, the sample of this study consisted of two parts, namely the management of the Syariah Bank Mandiri Branch of Baubau, namely as follows:

a. 1 (one) head of the Baubau Bank Syariah Mandiri Branch.

b. 2 (two) company members handling credit, at Bank Syariah Mandiri Baubau Branch.

c. 10 (ten) customers who use collateral on land rights.

The data analysis method used is qualitative analysis, where the data that has been obtained from the results of research are selected and systematized based on the quality and correctness in accordance with the research material, to then be associated with existing theories. From the results of the analysis are expected to answer the problems raised. In accordance with this study, which examines the credit agreement between the Bank Syariah Mandiri Baubau Branch with customers, the discussion is used with a qualitative descriptive analysis with a percentage method approach. The formula used is.

$$
\mathrm{P}=\frac{\boldsymbol{F}}{\boldsymbol{N}} \times 100 \%
$$

Information:

$$
\begin{aligned}
& \mathrm{P}=\text { Percentage } \\
& \mathrm{F}=\text { Frequency } \\
& \mathrm{N}=\text { Number of Respondents }
\end{aligned}
$$

\section{RESULTS AND DISCUSSION}

\subsection{Form of Legal Protection for Customers in Financing Agreement with Collateral Right to Land at Bank Syariah Mandiri}

The total number of customers in the Bank Syariah Mandiri Baubau Branch Office at the time of the study was 3,095 people and the number of customers with land rights was 222 people. The form of legal protection for customers, according to Hendra Surahman Saputra, is a micro 
financing sale based on an interview on July 4, 2019, that every funding file from customers will be kept in a strong room and secured in a vault, which is always monitored through Closed Circuit Television (CCTV) and alarm. So, every data collected by the customer will be guaranteed by the Bank Syariah Mandiri Baubau Branch Office both from the danger of fire, flood, theft and others with a 24-hour guard system.

The form of customer legal protection in financing agreements with collateral for land rights at the Bank Syariah Mandiri Baubau Branch Office guaranteed article 38 paragraph (1) of the Republic of Indonesia Law No. 21 of 2008 concerning Sharia Banking which reads: "Sharia Banks and Sharia Business Units must implement risk management, the principle of getting to know customers, and customer protection".

Based on interviews with customers, namely Mr. Adi and Mr. Joko on August 21, 2019, they stated that the service system at Bank Syariah Mandiri Baubau Branch was very good because the contract was always instructed to be read in advance by prospective customers (mudharib) before they decided to agree on financing and after that explained by the bank and if the mudarib lack of understanding can ask directly so they really do not feel cheated by the financing program.

\subsection{Form of Legal Protection for Creditors in Financing Agreement with Collateral Rights to Land at Bank Syariah Mandiri}

The form of legal protection for creditors is based on Article 1 number 25 of the Law of the Republic of Indonesia Number 21 of 2008 concerning Sharia Banking, it is explained that the definition of financing is the provision of funds or claims equivalent to that in the form of:

a. Profit sharing transactions in the form of mudharabah and musyarakah;

b. Leasing transactions in the form of ijarah or leasing in the form of ijarah muntahiya bittamlik;

c. Buying and selling transactions in the form of murabahah, salam, and istishna receivables;

d. Loan and loan transactions in the form of qaradh receivables; and

e. Service lease transactions in the form of ijarah for multiservice transactions based on agreements and agreements between Sharia Banks and/or Sharia Business Units and other parties that require parties to be financed and/or given fund facilities to return the funds after a certain period of time in exchange for ijarah, without compensation, or profit sharing. In the provisions of this article, what is meant by an agreement or loan agreement is a credit/financing agreement, where an agreement must be made in written form.

The agreements in the Banking Credit Agreement must be made in written form. This provision is contained in the elucidation of article 8 of Act Number 10 of 1998 concerning amendments to Act Number 7 of 1992 concerning Banking, which requires banks as lenders to make written agreements. The banking agreement must be in written form as stipulated in the main banking provisions by Bank Indonesia as referred to in article 8 paragraph (2) of the Banking Act. According to Badriyah Harun, the main provisions stipulated by Bank Indonesia are:

a. Provision of credit or financing based on sharia principles made in the form of a written agreement;

b. Banks must have confidence in the ability and capability of debtor customers, which among others are obtained from a careful assessment of the character, abilities, capital, collateral and business prospects of the debtor customers;

c. The Bank's obligation to compile and implement procedures for granting credit or financing based on sharia principles;

d. The bank's obligation to provide clear information about the procedures and terms of credit or financing based on sharia principles;

e. Prohibition of banks to provide credit or financing based on sharia principles with different requirements to debtor customers and / or affiliated parties;

f. Settlement of disputes [13].

After the process of binding guarantees with the clause granting mortgage rights by making the Deed of Granting Mortgage by the Acting Authority that contains promises protecting the creditor, so that the credit agreement can guarantee the repayment of creditors' creditors, it is necessary to process the encumbrance of the Mortgage in the form of the Deed of Rights. carried out through 2 (two) stages, namely through the process of registration and issuance of mortgage rights in the form of a Mortgage Certificate. As a proof of the existence of Mortgage with an executive power as the basis or basis for execution if the debtor breaks promise later.

The form of legal protection given to creditors when debtors default according to the explanation of article 10 of Law Number 4 of 1996 is in the form of a credit agreement itself which is contained in written form, which is either in the form of a deed under the hand or an authentic deed. According to the author, what further guarantees the creditor's right to recover his receivables when the debtor defaults is with a credit agreement with an authentic deed. This authentic deed has the advantage that it can be requested for a Grosse Acknowledgment of Debt which has an executorial power and becomes the basis for execution if the debtor is injured, but based on general explanation of number 9 and explanation of Article 14 paragraph (2) of the Mortgage Rights Certificate, a Certificate has been issued Land Rights as a substitute for the Grosse Deed Acknowledgment which has the same function.

Act Number 4 of 1996 concerning Mortgage Rights and Objects Related to Land, of course, provides legal protection to creditors in this case the Bank Syariah Mandiri Baubau Branch Office when the debtor / customer defaults in the loan granting process carried out by the party the bank as the creditor to the debtor, the possibility of becoming a risk such as failure or bottlenecks in paying off debts by the debtor is very large. So that a material security is required by the bank to the debtor to guarantee the repayment of the credit. The most widely used collateral is land rights, because the value or price tends to increase. The guarantee institution deemed effective and safe by banking institutions is the Underwriting Right, this is because it is easy to identify the object of the Underwriting Right and is clear 
and easy in the execution of its execution, and must be paid in advance from other bills with the proceeds from the auction of the Underwriting Right object, and the Underwriting Certificate has an executive power.

Based on the foregoing, it is clear that legal protection is given to creditors through Law Number 4 of 1996 concerning Mortgage Rights and Land Related Items which took effect on April 9, 1996.

\subsection{Promises contained in the Deed of Granting Coverage Rights Based on Article 11 paragraph (2) of Law Number 4 of 1996 concerning Mortgage Rights and Land-Related Items}

All promises contained in this article do not absolutely provide legal protection to creditors, but only a part of the promises that provide protection for creditors if the debtor defaults. Provisions in Article 11 paragraph (2) of Law Number 4 of 1996 concerning Mortgage Rights and Land Related Items reads:

a. Promises that limit the authority of the Underwriting Right provider to lease the object of the Underwriting Right and/or determine or change the lease period and / or receive the rent in advance, except with prior written approval from the Underwriting Right Holder;

b. Promises that limit the authority of the Underwriting Right provider to change the form or composition of the Underwriting Right object, except with prior written approval from the Underwriting Right Holder;

c. Promises that give authority to the Underwriting Right holder to manage the Underwriting Right object based on the stipulation of the Chairperson of the District Court whose jurisdiction covers the location of the Underwriting Right object if the debtor truly fails the promise;

d. Promises that give authority to the Underwriting Right holder to save the Underwriting Right object, if it is necessary for the execution or to prevent the abolition or cancellation of the rights which become the Underwriting Right object because the provisions of the Law are not fulfilled or violated;

e. Promise that the first Mortgage holder has the right to sell on his own authority the Mortgage object if the debtor fails to promise;

f. Promise that the Underwriter Right will not relinquish his rights to the Underwriting Right object without prior written approval from the Underwriting Right Holder;

g. The promise that the Underwriting Right holder will obtain all or part of the compensation received by the Underwriting Right Provider for repayment of his receivables if the Underwriting Right object is waived by the Underwriter or revoked his rights in the public interest;

h. The promise that the Underwriting Right Holder will obtain all or part of the insurance money received by the Underwriting Right Provider for the payment of his receivables, if the Underwriting Right object is insured; i. The promise that the Underwriting Right provider will vacate the Underwriting Right object at the time the execution of the Underwriting Right.

Mudharabah financing agreement according to [14] is a financing that contains risks caused by:

a. Side streaming, which is the customer uses the funds not as stated in the contract.

b. Deliberate and deliberate mistakes.

c. Moral hazard (actions that cannot be observed and adverse selection (entrepreneur ethics that are inherently unknowable to the capital owner).

The negligence of the customer (mudharib) against the creditor in a financing agreement with collateral for land rights at Bank Syariah Mandiri Baubau Branch Office which is a bad financing, based on the results of an interview on August 29, 2019 with Mr. Abrianus Tohamba his position is the branch manager at Bank Syariah Mandiri Office Baubau Branch, he stated during the establishment of the Bank Syariah Mandiri the Baubau Branch up to now there has never been any jam financing by customers, this is because the Bank Syariah Mandiri Baubau Branch Office has anticipated the rigorous financing process with collateral for land rights, namely by conducting a search or whether the land is in accordance with what is described by the customer (mudharib) or not, so if it is not appropriate then it will not be given, for example mudharib says that the land used as collateral is his property turns out to be disputed land, then it will not be cleared rikan or the land is located around a cemetery, it will not be given funding, because even though at auction the selling price will fall or low. So, the basis carried out by Bank Syariah Mandiri Baubau Branch is the principle of prudence and background of the customer in this case the feasibility of channeling funds to mudharib candidates.

This is in accordance with Article of the Law of the Republic of Indonesia Number 21 Year 2008 concerning Sharia Banking which reads: "Sharia Banking in conducting its business activities is based on Sharia principles, economic democracy, and prudential principles" and Article 23 paragraph (1) and (2) Law of the Republic of Indonesia Number 21 Year 2008 concerning Sharia Banking, namely:

a. Sharia Banks and/or Sharia Business Units must have confidence in the willingness and ability of prospective Facility Recipient Customers to pay off all obligations in time, before the Sharia Bank and/or channels funds to the Facility Recipient Customers.

b. To obtain confidence as intended in paragraph (1), Sharia Banks and/or are required to conduct a careful assessment of the character, abilities, capital, collateral, and business prospects of prospective Facility Recipient Customers.

But added by Mr. Hendrawan Adi Putra who is a micro financing sale namely the results of an interview on August 28, 2019 stated that if there is bad financing (default) then the method of settlement that will be taken by the Bank Syariah Mandiri Baubau Branch Office is to conduct a financing restructuring, filing a claim to insurance, voluntary collateral sales, underhand sales and auctions. 


\subsection{Financing Agreement Process with Collateral Rights to Land Between the Customer and Bank Syariah Mandiri}

The financing contract process with collateral for land rights between the customer (mudharib) and Bank Syariah Mandiri Baubau Branch Office begins with the terms of financing between the customer and the Bank Syariah Mandiri Branch of Baubau, namely:

a. Fill out the application form.

b. Photocopy of Family Card and marriage certificate.

c. Photocopy of Identity Card of husband and wife.

d. Original salary slip/income statement/Business License.

e. Photocopy of Taxpayer Identification Number.

f. Photocopy of the last 6 months savings book.

g. Photocopy of guarantee of land certificate and Building Permit and Land and Building Tax.

After all the conditions have been entered by the customer, the Bank Syariah Mandiri Baubau Branch Office will conduct a review of the object that is used as collateral to see whether in accordance with the data or information provided by the customer and to see the level of eligibility in this case whether the customer can be provided financing in accordance with the application or not. For example, although data from customers is in accordance with the conditions to be guaranteed, but it is located near the cemetery, according to the Bank Syariah Mandiri Baubau Branch Office is not feasible to provide because if there is a default on the financing contract, the selling value is low. And these requirements have been discussed from the beginning by the bank to prospective customers transparently. If the Bank Syariah Mandiri Baubau Branch Office considers it feasible to provide financing, the customer will be contacted by telephone to complete the collateral requirements in the form of original land certificates, original Building Permit, Original Decree as a Civil Servant or Business license and business location permit for entrepreneurs and some Rp. 6000. After that, the bank shows some financing contract material to customers about various provisions contained in the contract. Provisions contained in the contract are to be read and understood by each customer and if the customer agrees, the financing agreement between the customer and the Bank Syariah Mandiri Baubau Branch Office Interviews can be carried out with the service rebirth and Bank Mandiri Syariah Branch Operations Mr. La Ode Muliadi on August 12, 2019.

A financing agreement relating to collateral for land and buildings is a murabahah contract which is an agreement between the Bank Syariah Mandiri Baubau Branch Office and the customer, where the bank provides financing for the purchase of raw materials or other working capital needed by the customer to be paid. return by the customer in the amount of the bank selling price (the purchase price of the bank plus profit margins) at the time determined by the Bank Syariah Mandiri Baubau Branch Office with the customer's approval as evidenced by a promissory note (acceptance/promissory note) signed by the customer, where the sound of promissory note stating that with this promissory note promises without conditions to pay to PT. Bank Syariah Mandiri Jakarta or order an amount of money at PT Bank Syariah Mandiri Baubau Branch Office located at Jalan Yos Sudarso Number 33 Baubau City. This promissory note was issued with the provisions "without payment non-protest" and "without fee" according to Article 176 of the Commercial Code jucto Article 145 KUHD).

Bank Syariah Mandiri Baubau Branch Office, also gives freedom to customers in completing payments or financing installments at PT Bank Syariah Mandiri Baubau Branch Office.

The financing contract process with collateral for land rights between the customer and Bank Syariah Mandiri Baubau Branch Office is also prohibited from giving gifts or rewards or gifts in any form related to the provision of financing facilities with the aim of smoothing financing for any reason as stated in the prohibition for employees or employees of Islamic Banks Mandiri Baubau Branch Office. This is based on the Code of Ethics or Code of Conduct (COC), where the contents of the letter affirm that:

a. We, the entire staff and leadership of PT Bank Syariah Mandiri, "do not accept gifts of any kind in the form of money or goods" related to the provision of financing facilities.

b. We urge and prohibit the father or mother to provide gifts in any form whether in the form of money or goods related to the provision of financing by PT Bank Syariah Mandiri.

Both of these are the commitments of all employees or employees of PT Bank Syariah Mandiri Baubau Branch Office that carries out storage as regulated in the code of ethics. PT Bank Syariah Mandiri Baubau Branch Office has one of the contracts, namely murabaha. This murabahah agreement is an agreement agreed between the Sharia Bank and the customer, in which the Bank provides financing for the purchase of raw materials or other performance capital needed by the customer, which will be paid back by the customer at the bank's selling price (bank purchase price + profit margin) at the set time. So in this case, if the customer wants to buy a car, then during the payment period by the customer, then the car still belongs to PT Bank Syariah Mandiri Baubau Branch Office and if the Motor Vehicle Ownership Book has been published, then the customer must make a deposit to PT Bank Syariah Mandiri Office The Baubau branch is a guarantee in addition to the guarantee of land rights that will be made in the form of a guarantee handover.

\section{CONCLUSIONS}

Based on the problem formulation, results and discussion, conclusions can be drawn as follows:

a. Forms of legal protection for customers (mudharib) are:

1) The Bank Syariah Mandiri Baubau Branch Office will store the mudharib file into a hasanah room (strong room) and secure it in a monitored safe via closed circuit television (cctv) and give an alarm, where the room is anti-fire and flood and theft;

2) There is a security guarantee from the officer (the Sharia Bank Mandiri Security Unit of the Baubau Branch Office with a 24-hour guard system, so that 
[2] Rendra Yozar Dharmaputra dan Siregar Januari, "Implementation of Working Capital Loan Agreement in Band Mandiri (Persero) Tbk. Binjai Branches in The Review Of Law Number 8 of 1999 Concerning Consumer Protection," Mercatoria, vol. 3, no. 2, pp. 71-87, 2010.

[3] M. Pratama, "Implementation of Legal Protection for Creditors in Providing Working Capital Loans without Collateral (Study in Danamon Savings and Loans Turen Unit)," Arena Huk., vol. 7, no. 1, pp. 26 47, 2014.

[4] Mohammad Wisno Hamin, "Legal Protection For Bank Customers (Debtors) As a Consumer of Bank Service Users of Risk in The Bank Credit Agreement," Lex Crim., vol. VI, no. 1, pp. 115-122, 2017.

[5] Rilda Murniati, "Legal protection of customer funds at a bank through a deposit insurance agency," Fiat Justitia J. Ilmu Huk., vol. 7, no. 3, pp. 304-316, 2013.

[6] M. Santi, “Customer Protection Study According to RI Law Number 21 Year 2008 Regarding Sharia Banking,”J. Episteme, vol. 7, no. 437-462, 2012.

[7] M. dan D. I. N. Paramitha, Putu Ikaputri Ayu, "Legal Protection For Creditors in Credit Agreement With Guarantee of Rights (Study in Bank Bni Branch, Gatsu Barat)," E-Journal Ilmu Huk. Kertha Semaya, vol. 5, no. 5, pp. 1-11, 2017.

[8] M. A. A. Purnomo, "Legal Protection For Genders of Rights That is Not Debtor in Credit Agreements," UNNES LAW J., vol. 3, no. 1, pp. 62-68, 2014.

[9] P. Rahmawati, "The Legal Consequences of Credit Agreements with Non-MOVING Goods Collateral Made Under the Hand at PT. Indonesian People's Bank (Persero) Branch Tegal City Unit," Priv. Law, vol. IV, no. 2, pp. 72-79, 2016.

[10] L. Sulastri, "Construction of Debtor Legal Protection in Settlement of Problem Credit with the Implementation of Mortgage Guarantee Auction," J. Pembaharuan Huk., vol. 2, no. 1, pp. 86-101, 2015.

[11] Arikunto, Suharsimi. 2012. P Research procedure (A Practice Approach), Rineka Cipta Jakarta.

[12] Tjahjono, Heru K. 2009. Business Research Methods. Yogyaakarta. Visi Solusi Madani, Yogyakarta.

[13] Badriyah Harun. 2010 Troubled Credit Dispute Settlement Pustaka Yustisia.Yogyakarta

[14] Any Nugroho 2015. Syariah Banking Law Aswaja Prssindo.Yogyakarta
[1] C. R. Lestari, "Settlement of Bank Bad Debt Through the Execution Parate," Kanun J. Ilmu Huk., vol. 19, no. 1, pp. 81-96, 2017. 